\title{
Strategi Inovasi pada Industri Kreatif Digital: Upaya Memperoleh Keunggulan Bersaing pada Era Revolusi Industri 4.0
}

\author{
Rofi Rofaida $^{\left.1^{*}\right)}$, Suryana $^{2)}$, Asti Nur Aryanti ${ }^{3)}$, Yoga Perdana ${ }^{4)}$ \\ ${ }^{1 * 2,4)}$ Fakultas Pendidikan Ekonomi dan Bisnis, Universitas Pendidikan Indonesia, Bandung,Indonesia \\ ${ }^{3)}$ Sekolah Tinggi Ilmu Ekonomi Indonesia Membangun (STIE INABA), Bandung, Indonesia \\ e-mail: rofi.rofaida@upi.edu ${ }^{1 *}$
}

\begin{abstract}
Abstrak
Penelitian ini bertujuan untuk mengembangkan strategi inovasi sebagai upaya meningkatkan kinerja bisnis dan keunggulan bersaing industri kreatif digital di era revolusi industri 4.0. Penelitian ini merupakan penelitian kualitatif. Teknik penarikan sampling yang digunakan adalah purposive sampling. Ukuran sampel yang digunakan adalah 50 pelaku usaha industri kreatif digital di Provinsi Jawa Barat yang mengetahui dengan jelas proses inovasi pada industri kreatif digital. Data dikumpulkan melalui metode observasi, penyebaran kuesioner, in depth interview dan focus group discussion /FGD dengan pelaku industry kreatif digital, tim peneliti, komunitas industri kreatif digital, dan expert di bidang industri kreatif. Hasil penelitian menunjukkan bahwa industri kreatif digital di Jawa Barat memiliki permasalahan dalam menetapkan strategi inovasi yang tepat. Rekomendasi yang diberikan adalah penetapan strategi inovasi pada tiga aspek yaitu inovasi produk, inovasi proses, dan inovasi pemasaran. Hasil penelitian dapat memberikan implikasi bagi perusahaan dalam bentuk strategi inovasi yang tepat dan membantu pemerintah daerah dalam merumuskan kebijakan yang tepat bagi tumbuh dan berkembangnya industri kreatif digital di Jawa Barat. Penelitian dengan topik inovasi pada industri kreatif digital masih jarang dilakukan sehingga diharapkan hasil penelitian ini bisa menjadi kebaruan/originalitas yang dapat memperkuat penelitian dengan topik yang lain pada industri kreatif digital
\end{abstract}

Kata Kunci: strategi inovasi; industri kreatif digital; keunggulan bersaing

\begin{abstract}
The purpose of this research was to develop an innovation strategy to improve business performance and competitive advantage of digital creative industries in the industrial revolution era 4.0. This research was a qualitative research. The sampling technique used was purposive sampling. with a sample size of 50 digital creative industry entrepreneurs in West Java who clearly knew the innovation process in the digital creative industry. Data was collected through observation methods,kuessioner, in depth interviews and focus group discussions / FGD with digital creative industry, research team, digital creative community, and expert in creative industry. The results showed that the digital creative industry in West Java had problems in determining the right innovation strategy. The recommendation given was the establishment of an innovation strategy on three aspects namely product innovation, process innovation, and marketing innovation. The results of the study were expected to provide implications for companies in the form of innovation strategies and policies that can be issued by local governments for the growth and development of digital creative industries in West Java. Research on the topic of innovation in the digital creative industry is still rarely done so it is hoped that the results of this study can be novelty / originality that can strengthen research with other topics in the digital creative industry
\end{abstract}

Keywords: innovation strategy; digital creative industries; competitive advantage 


\section{PENDAHULUAN}

Ekonomi kreatif (ekraf) adalah konsep ekonomi baru yang menghasilkan produknya melalui optimalisasi ide kreatif, bakat individu, keterampilan, dan inovasi. Ekraf mulai berkembang menjadi tulang punggung perekonomian di Indonesia seiring dengan turunnya kontribusi sektor migas terhadap perekonomian Indonesia. Ekraf mampu menjadi sumber pertumbuhan dan kekuatan baru bagi perekonomian nasional yang berkelanjutan karena ide, daya kreasi dan inovasi merupakan sumber daya terbarukan dan tidak terbatas yang tidak pernah berhenti untuk selalu memberikan nilai tambah terhadap produk yang dihasilkan. Motor penggerak dari ekonomi kreatif adalah industri kreatif. Secara ekonomi, peran industri kreatif dapat dilihat dari dua sudut pandang, yaitu kontribusi terhadap pendapatan nasional dan penyerapan tenaga kerja. PDB industri kreatif atas dasar harga yang berlaku terus naik, dari 525,96 trilyun (tahun 2010) menjadi 922,59 trilyun (tahun 2016). Kinerja positif lainnya dari industri kreatif adalah peran sektor ini terhadap penyerapan tenaga kerja. Selama tahun 2015-2016, jumlah penduduk yang bekerja di sektor industri kreatif cenderung mengalami peningkatan dari 15,96 juta orang pada tahun 2015 (13,90\% dari tenaga kerja nasional) menjadi 16,91 juta orang pada tahun 2016 (14,28\%). (Badan Pusat Statistik dan Badan Ekonomi Kreatif, 2017).

Dihadapkan pada ASEAN Economic Community (AEC) dan era revolusi industri 4.0, industri kreatif nasional harus mulai berubah dengan berbasis teknologi, memanfaatkan teknologi dalam aktifitas bisnisnya. Cetak biru industri kreatif tahun 2015-2025 menyatakan bahwa peningkatan daya saing industri kreatif melalui optimalisasi pemanfaatan IPTEK, pengembangan kreativitas dan kelembagaan industri kreatif, menjadi fokus pengembangan subsektor ekonomi kreatif pada tahun 2015-2019 (Kemenparekraf, 2015). Didalam roadmap strategi pengembangan subsektor ekonomi kreatif tahun 2015-2019, industri kreatif digital menjadi salah satu prioritas pengembangan industri kreatif di Indonesia. Hal ini didorong pula oleh perkembangan revolusi industri yang mengarah ke revolusi industri 4.0.

Beberapa provinsi telah ditetapkan sebagai pusat unggulan industri kreatif digital, diantaranya adalah Jawa Barat dan DKI Jakarta. Berkaitan dengan fenomena tersebut, maka industri kreatif digital yang memang memproduksi produk-produk digital dituntut untuk melakukan inovasi yang berkelanjutan untuk mampu merancang produk digital sesuai dengan keinginan konsumen (consumer based). Perkembangan industri kreatif digital dihadapkan pada beberapa kendala, diantaranya adalah tantangan pasar yaitu tantangan yang terkait dengan perilaku konsumen yang memiliki kemampuan memilih produk digital secara lebih selektif dan persaingan diantara pelaku usaha industri kreatif digital. Kunci utama untuk memenangkan persaingan pada industri dimana lingkungan persaingan sangat tinggi dan perilaku pasar yang selektif adalah melalui strategi inovasi. Industri kreatif digital dituntut untuk selalu berinovasi baik dalam proses maupun produk sehingga memiliki keunikan yang membedakan produk yang dihasilkan dengan pesaingnya. Penelitian ini memiliki tujuan untuk memperoleh gambaran proses inovasi yang saat ini dilaksanakan dan mengembangkan strategi inovasi yang harus dilakukan oleh industri kreatif untuk memenangkan persaingan. Penelitian dilakukan di 
Provinsi Jawa Barat, sebagai salah satu pusat industri kreatif digital di Indonesia. Hasil penelitian dapat memberikan manfaat minimal kepada pelaku usaha dan kepada pemerintah. Bagi pelaku usaha, hasil penelitian dapat dijadikan base line study untuk mengembangkan strategi novasi yang tepat sedangkan bagi pemerintah dapat membantu dalam merumuskan needs assessment/analisis kebutuhan untuk meningkatkan kompetensi inovasi pelaku usaha dan mengembangkan kebijakan uantuk menciptakan iklim bisnis yang kondusif.

\section{TINJAUAN PUSTAKA}

\section{Industri Kreatif Digital dan Revolusi Industri 4.0}

Pada revolusi industri 4.0, terjadi penggabungan teknologi otomatis dan cyber sehingga dalam aktifitas bisnis terjadi otomatisasi serta pertukaran data (automation and data exchange). Seperti diketahui bahwa pada revolusi industri 4.0 ini banyak perusahaan yang telah menerapkan konsep digitalisasi/otomatisasi dalam setiap proses operasionalnya. Perkembangan teknologi digital telah memberikan pengaruh signifikan pada sektor ekonomi kreatif di Indonesia. Pemanfaatan teknologi digital sudah dapat dirasakan dampaknya di berbagai sub sekctor seperti desain, musik, seni rupa dan sub sektor lainnya (Putra, C.N, 2018). Berkaitan dengan perkembangan tersebut, peluang industri kreatif digital semakin besar. Industri kreatif digital adalah industri kreatif yang menggabungkan unsur kreatifitas dan pemanfaatan teknologi digital dalam proses maupun produk akhirnya. Pada rantai kreasi dan produksi, teknologi dibutuhkan untuk memperoleh, menyebarkan, dan melakukan pertukaran informasi dan memperkaya ide kreasi. Teknologi informasi dibutuhkan pada saat proses produksi melalui pemanfaatan internet dalam pencarian desain-desain baru. Teknologi informasi juga dibutuhkan dalam proses distribusi, promosi, dan transasksi penjualan sehingga proses berjalan lebih efektif dan efisien.

Potensi perkembangan industri ini karena beberapa faktor yaitu: perkembangan teknologi informasi sebagai faktor utama berkembang dengan cepat, akses kepada pusat informasi melalui internet jauh lebih mudah, proses social innovation berjalan mulus, setiap wilayah memiliki keunikan potensi budaya lokal dan keterbukaan masyarakat terhadap budaya modern, terdapat sumber sumber pengetahuan seperti banyaknya kampus yang menjadi sumber SDM yang berkualitas, memiliki kreatifitas dan inovasi yang tinggi. Perpaduan berbagai faktor di atas menghasilkan bertemunya unsur estetik dan teknologi yang menghasilkan industri kreatif digital yang khas.

Namun demikian, keberadaan industri kreatif digital tidak sepenuhnya berjalan sesuai harapan terdapat tantangan-tantangan yang dihadapi. Adapun tantangan tersebut diantaranya adalah

1. Tantangan pasar, terkait dengan pengetahuan dan keinginan konsumen untuk memperoleh produk yang memiliki kualitas yang tinggi dan inovatif untuk memenuhi kebutuhan konsumen. Tantangan pasar muncul juga dari pesaing yang menawarkan produk produk yang inovatif. Dalam konteks tingkat persaingan yang tinggi maka keunggulan bersaing akan ditentukan oleh kualitas dan inovasi (Heizer dan Render, 2017). Industri kreatif digital dituntut untuk selalu 
melakukan inovasi.

2. Tantangan transfer pengetahuan dan teknologi. Industri kreatif digital dicirikan oleh penguasaan dan pemanfaatan teknologi digital. Teknologi digital itu sendiri berkembang cepat dan dinamis sehingga perlu adanya kebijakan dari pemerintah untuk bisa menjembatani alih teknologi ini dari lembaga penelitian, dan universitas dengan industri. Peran pemerintah sangat sentral dan penting karena selama ini belum adanya link and match/kesesuaian antara haril penelitian dengan kebutuhan industri.

3. Tantangan sumberdaya manusia. Kompetensi sumberdaya manusia menjadi kata kunci untuk memperoleh keunggulan bersaing pada industri yang memiliki karakteristik persaingan bisnis yang tinggi dan teknologi yang berkembang cepat (Chodorek dan Copernicus, 2012). Kompetensi yang harus dimiliki adalah pengetahuan dasar tentang teknologi digital, konten atau isi dan pemrograman. Dibutuhkan juga sumberdaya manusia yang inovatif dan kreatif sehingga proses dan produk akhir yang dihasilkan memiliki keunikan yang berbeda dengan produk lain. Kompetensi manajerial membutuhkan pembinaan dan pendampingan agar mampu mengintegrasikan sisi produksi dengan manajemen keuangan, pemasaran dan sumberdaya manusia.

4. Tantangan birokratis, terkait dengan aksesabilitas pada sumber pembiayaan untuk meningkatkan kapasitas usaha di lingkungan industri kreatif digital, pembinaan industri yang tidak fokus dari kelembagaan baik pemerintah ataupun swasta yang bertanggungjawab. Tantangan birokratis lainnya adalah komunikasi pemerintah dan industri yang belum optimal. Kebijakan yang ada belum bersifat lintas sektoral sehingga implementasinya berjalan sendiri sendiri dan sporadis sehingga hasilnya tidak maksimal

\section{Strategi Inovasi}

Secara umum inovasi adalah suatu proses dan/atau hasil pengembangan pemanfaatan suatu produk/ sumber daya yang telah ada sebelumnya, sehingga memiliki nilai yang lebih berarti. Inovasi diartikan sebagai proses dari mulai penemuan ide dan gagasan, proses produksi sampai kepada proses pemasaran (Rogers, 2003; Urabe, 1998; Van de Ven, 2016). Ada juga yang mengatakan arti inovasi adalah suatu pembaharuan terhadap berbagai sumber daya sehingga memberikan manfaat yang lebih/value added bagi manusia. Faktor yang sangat penting dalam menentukan proses inovasi adalah kemajuan teknologi dan ilmu pengetahuan. Kemajuan IPTEK merupakan faktor penting dalam menentukan kualitas, positioning, kinerja perusahaan, dan keuntungan sekaligus memenangkan persaingan dalam revolusi industri 4.0. Pada awalnya konsep inovasi digunakan dalam konteks makro bahwa inovasi adalah sebagai kekuatan pendorong yang penting (critical driving force) dalam pertumbuhan ekonomi. Namun saat ini konsep inovasi telah mengalami pergeseran ke dalam konteks mikro yaitu terkait dengan proses inovasi yang terjadi di dalam perusahaan (Xu dkk., 2006). Inovasi 
diartikan sebagai tranformasi atau implementasi ide atau gagasan didasarkan pada daya kreativitas untuk menghasilkan proses dan produk yang memiliki nilai tambah/value added yang lebih tinggi.

Inovasi dipahami sebagai 'as the introduction of something new and useful in product, processes, or service' (Hernandez, 2010). Inovasi adalah menghasilkan sesuatu yang baru dan bernilai, baik dalam produk, proses, atau jasa. Perusahaan yang berhasil menciptakan keunggulan bersaing (competitive advantage) adalah perusahaan yang mampu untuk menciptakan sebuah inovasi dan kreativitas melalui proses inovasi yang efektif dan terencana. Untuk mendukung perubahan tersebut dibutuhkan strategi-strategi yang efektif untuk menciptakan produk baru dan pengembangan produk dengan meningkatkan kemampuan kreatif dari para karyawan atau anggota dalam sebuah perusahaan.

Strategi inovasi mengacu kepada teori-teori tentang inovasi yang dikembangkan oleh para ahli. Teori inovasi berkembang sejalan dengan kebutuhan dunia industri dan perkembangan teknologi. Pada teori dasar inovasi, inovasi terbagi menjadi empat jenis, yaitu inovasi produk, inovasi proses, inovasi pemasaran, dan inovasi perusahaan. Inovasi produk adalah pengenalan barang atau jasa yang belum pernah ada atau telah melalui proses pengembangan produk yang menyebabkan terjadinya peningkatan manfaat dari produk tersebut. Inovasi proses adalah penerapan metode produksi atau metode distribusi yang baru atau metode lama yang telah diperbaiki sehingga terjadi peningkatan kinerja yang signifikan. Inovasi pemasaran bertujuan meningkatkan kinerja pemasaran melalui kebijakan pengemasan, penempatan produk, promosi produk, atau harga. Inovasi pemasran bertujuan untuk mengingkatkan penjualan, memenuhi kebutuhan konsumen, membuka pasar baru, dan menempatkan produk perusahaan dalam pasar. Terakhir adalah inovasi perusahaan, yaitu penerapan metode perusahaan baru pada praktik bisnis, perusahaan tempat kerja atau hubungan eksternal perusahaan.

Selanjutnya terjadi pergeseran konsep inovasi dengan diperkenalkan sepuluh tipe inovasi (ten types of innovation) dari Keeley et al. (2013) yang menyatakan bahwa terdapat sepuluh tipe inovasi yang dapat digunakan dalam pengembangan bisnis. Tipe inovasi tersebut menjadi terobosan baru bagi perusahaan yang terkadang hanya fokus pada inovasi produk dan pelayanan saja. Jika perusahaan melakukan inovasi dibeberapa bidang maka akan menjadi lebih sulit bagi para pesaing untuk dapat bersaing dengan perusahaan. Keeley et al. (2013) menyatakan terdapat sepuluh tipe inovasi yang diterapkan oleh perusahaan dalam pengembangan bisnis. Sepuluh tipe inovasi dibagi menjadi tiga kategori besar yaitu configuration, offering dan experience. Ketiga kelompok tersebut merupakan strategi inovasi perusahaan yang digunakan dalam rangka meningkatkan aspek internal perusahaan sebagai sarana untuk mempromosikan hasil eksternal yang lebih baik.

Configuration merupakan strategi perusahaan yang digunakan dalam rangka meningkatkan aspek internal perusahaan sebagai sarana untuk mempromosikan hasil eksternal yang lebih baik, terdiri dari profit model, network, structure, dan process. Profit Models adalah bagaimana perusahaan mendapatkan keuntungan dengan cara baru (new profit) yang membedakan perusahaan dengan kompetitornya. Dapat juga diartikan bagaimana perusahaan akan mendapatkan keuntungan. Network innovation merupakan inovasi perusahaan dalam menciptakan nilai melalui hubungan dengan pihak 
lain atau cara perusahaan dalam memanfaatkan jaringan untuk menciptakan nilai yang lebih inovatif. Structure innovation berhubungan dengan memperbaiki struktur perusahaan dengan cara kompilasi dan menyelaraskan bakat dan asset perusahaan memiliki dalam rangka untuk menemukan keberhasilan perkembangan yang lebih baik atau pengelolaan dan penyelarasan talenta dan asset perusahaan dengan cara yang untuk menciptakan nilai yang inovatif. Process innovations merupakan inovasi berbasis proses tersebut dengan menganalisis dan meningkatkan nilai perusahaan melalui prosesnya (dari input sampai output).

Termasuk dalam offering adalah product performance dan product system, dimana perusahaan mengembangkan fitur yang berbeda dan fungsionalitas atas produk atau jasa yang berbeda yang membedakan perusahaan dan kompetitornya melakui kualitas produk seperti atribut produk, keandalan, daya tahan, dan estetika. Product system menggambarkan layanan pelengkap untuk memperkuat product performance.

Experience terdiri dari service, channel, brand innovation, dan customer engagement. Service merupakan inovasi perusahaan untuk memperkuat nilai produk. Channel merupakan inovasi yang dilakukan perusahaan pada rantai distribusi barang dari produsen ke konsumen. Brand innovation merupaka inovasi perusahaan untuk memperkuat identitas produk. Terakhir adalah customer engagement yaitu menganalisis dan memperomosikan keterlibatan konsumen dengan perusahaan untuk menciptakan inovasi.

\section{METODE PENELITIAN}

Penelitian ini merupakan penelitian kualitatif. Teknik penarikan sampling yang digunakan adalah purposive sampling, yaitu penarikan sampel dengan tujuan tertentu. Ukuran sampel dalam penelitian kualitatif relatif kecil. Ukuran sampel dalam penelitian ini adalah 50 pelaku usaha industri kreatif digital di Jawa Barat yang mengetahui dengan jelas variabel yang diteliti, yaitu inovasi pada industri kreatif digital.

Data dikumpulkan melalui metode observasi, penyebaran kuesioner, in depth interview dan focus group discussion/FGD yang dilakukan tiga kali dengan melibatkan tim peneliti, industri kreatif digital, expert di bidang industri kreatif dan komunitas industri kreatif digital. Penelitian menggunakan cakupan waktu dari bulan Juni 2017 sampai dengan Maret 2019. Sejalan dengan tujuan penelitian ini, digunakan teknik analisis deskriptif, dengan tahapan sebagai berikut: menyusun data, tabulasi data, dan resource based view untuk merekomendasikan strategi inovasi untuk meningkatkan kinerja dan sekaligus keunggulan bersaing industri kreatif digital.

\section{HASIL DAN PEMBAHASAN}

\section{Karakteristik Responden}

Responden dalam penelitian ini adalah pengusaha industri kreatif digital Jawa Barat. Profil responden secara detail dijelaskan oleh Tabel 1. 
Tabel 1. Profil Responden

\begin{tabular}{ll}
\hline Uraian & Deskripsi \\
\hline Jenis usaha digital & Games (8\%); Animasi (19\%); Sosial Media (12\%); \\
& Web Developer (15\%), Software/Aplikasi (46\%) \\
Jumlah karyawan & $<5$ orang (38\%); 5-50 orang (50\%); 51-100 orang (12\%); \\
& $>100$ orang (0\%) \\
Lama usaha & $0-5$ tahun (88\%); 6-10 tahun (4\%); 11-15 tahun (4\%); \\
& $>15$ tahun (4\%)
\end{tabular}

Sumber: pengolahan data di lapangan

Jenis usaha industri kreatif digital meliputi games, animasi, sosial media, web developer, dan software/aplikasi. Sebagain besar responden yaitu $46 \%$ bergerak di bidang pembuatan dan pengembangan software/aplikasi. Pembuatan dan pengembangan software/aplikasi memiliki prospek yang sangat bagus karena semua jenis aktifitas ekonomi baik perdagangan, pendidikan, kesehatan dan sektor lainnya membutuhkan aplikasi untuk menunjang proses bisnis yang dilakukan.Dilihat dari indikator jumlah karyawan dan lama usaha, mayoritas industri kreatif digital (50\%) adalah UMKM karena memiliki 5-50 karyawan, dan masih memiliki pengalaman usaha sangat minim yaitu 0-5 tahun (88\% respoenden) sehingga belum memiliki sistem manajemen yang baik, termasuk perencanaan pengembangan bisnis dari sisi inovasi. Gambaran di atas menunjukkan bahwa peningkatan kapasitas inovasi industri kreatif digital melalui berbagai program pelatihan dan pendampingan masih harus ditingkatkan agar mampu meminimalisasi kekurangan yang timbul akibat business experience yang kurang dan untuk meningkatkan skala usaha.

\section{Strategi Inovasi}

Hasil penelitian terhadap industri kreatif digital di Jawa Barat yang dilakukan selama Juni 2017-Maret 2019 memberikan gambaran bahwa aspek inovasi menjadi salah satu faktor penghambat/bottleneck untuk tumbuh dan berkembangnya industri kreatif digital di Jawa Barat. Gambaran proses inovasi yang dilaksanakan industri kreatif digital di Provinsi Jawa Barat diukur melalui penilaian terhadap delapan indikator inovasi yang dikumpulkan dengan cara observasi, penyebaran kuesioner, dan in depth interview. Delapan indikator tersebut adalah. Hasil analisis terhadap proses inovasi secara detil dijelaskan oleh Tabel 2.

Dari Tabel 2 dapat dijelaskan bahwa gambaran proses inovasi pada industri kreatif digital di Provinsi Jawa Barat belum menunjukkan kinerja yang baik. Hanya pada indikator perusahaan fokus pada penelitian dan pengembangan dalam aktifitas bisnis, sebagian besar responden (64\%) menyatakan setuju bahwa mereka memberikan perhatian penuh pada aktifitas riset dan pengembangan. Hanya separuh responden (50\%) yang mengetahui teknologi baru yang dapat diterapkan dalam aktifitas bisnis, memiliki strategi bisnis terkait dengan 
Tabel 2. Gambaran Proses Inovasi pada Industri Kreatif Digital di Provinsi Jawa Barat

\begin{tabular}{|c|c|}
\hline Indikator & Hasil \\
\hline $\begin{array}{l}\text { 1. Perusahaan mengetahui teknologi baru } \\
\text { yang dapat diterapkan dalam aktifitas } \\
\text { bisnis }\end{array}$ & $\begin{array}{l}\text { Hanya separuh responden (50\%) menyatakan bahwa } \\
\text { perusahaan selalu mengetahui teknologi baru yang } \\
\text { dapat diterapkan dalam aktifitas bisnis }\end{array}$ \\
\hline $\begin{array}{l}\text { 2. Perusahaan fokus terhadap aktifitas } \\
\text { riset dan pengembangan (research and } \\
\text { development) }\end{array}$ & $\begin{array}{l}\text { Mayoritas responden (64\%) menyatakan bahwa } \\
\text { perusahaan fokus pada penelitian dan pengembangan } \\
\text { (research and development) dalam aktifitas bisnis }\end{array}$ \\
\hline $\begin{array}{l}\text { 3. Perusahaan melakukan investasi untuk } \\
\text { pengembangan produk baru }\end{array}$ & $\begin{array}{l}\text { Sebagian kecil responden }(43 \%) \text { melakukan investasi } \\
\text { untuk pengembangan produk baru }\end{array}$ \\
\hline $\begin{array}{l}\text { 4. Perusahaan terbuka terhadap ide baru } \\
\text { yang membawa pada peluang bisnis } \\
\text { baru }\end{array}$ & $\begin{array}{l}\text { Sebagian besar reponden (57\%) terbuka terhadap ide } \\
\text { baru yang membawa pada peluang bisnis baru }\end{array}$ \\
\hline $\begin{array}{l}\text { 5. Perusahaan menilai bahwa inovasi dan } \\
\text { kreatifitas merupakan bagian dari } \\
\text { strategi bisnis }\end{array}$ & $\begin{array}{l}\text { Hanya separuh responden ( } 50 \%) \text { menyatakan bahwa } \\
\text { mereka memiliki strategi bisnis terkait dengan inovasi } \\
\text { dan kreatifitas }\end{array}$ \\
\hline $\begin{array}{l}\text { 6. Karyawan didorong untuk } \\
\text { mengembangkan bisnis baru }\end{array}$ & $\begin{array}{l}\text { Sebagian besar reponden }(57 \%) \text { menyatakan bahwa } \\
\text { karyawan didorong untuk memiliki inovasi dan } \\
\text { kreatifitas untuk mengembangkan bisnis }\end{array}$ \\
\hline $\begin{array}{l}\text { 7. } \text { Keterlibatan seluruh komponen } \\
\text { perusahaan terlibat dalam mendorong } \\
\text { proses inovasi bisnis secara digital }\end{array}$ & $\begin{array}{l}\text { Sebagian kecil responden ( } 40 \%) \text { menyatakan bahwa } \\
\text { seluruh komponen didalam perusahaan terlibat dalam } \\
\text { inovasi bisnis secara digital }\end{array}$ \\
\hline $\begin{array}{l}\text { 8. Terdapat reward system bagi karyawan } \\
\text { yang kreatif dan inovatif }\end{array}$ & $\begin{array}{l}\text { Hanya separuh responden (50\%) menyatakan bahwa } \\
\text { perusahaan memberikan reward bagi karyawan yang } \\
\text { inovatif dan kreatif. }\end{array}$ \\
\hline
\end{tabular}

Sumber: pengolahan data di lapangan

inovasi dan kreatifitas, karyawan didorong untuk memiliki inovasi dan kreatifitas untuk mengembangkan bisnis, dan memberikan reward bagi karyawan yang inovatif dan kreatif. Bahkan untuk indikator melakukan investasi untuk pengembangan produk baru dan indikator keterlibatan komponen didalam perusahaan terlibat dalam inovasi bisnis secara digital, hanya sebagian kecil responden yang melakukannya. Sangat penting untuk meningkatkan kemampuan perusahaan untuk menciptakan inovasi dan kreatifitas melalui pemanfaatan teknologi baru. Dukungan sumber keuangan yang memadai juga menjadi faktor yang sangat penting. Keterlibatan seluruh komponen perusahaan dalam proses inovasi juga harus lebih ditingkatkan lagi sehingga inovasi bisa menjadi ruh atau budaya perusahaan yang dapat 
menggerakkan kinerja perusahaan kearah pencapaian tujuan yang telah ditetapkan dan keunggulan bersaing secara berkelanjutan. Inovasi menjadi kata kunci utuk memenangkan persaingan khususnya bagi produk yang memiliki product life cycle yang pendek, termasuk industri digital.

Hotho and Champion (2010) dan Lu and Mu (2011) menggambarkan bahwa industri kreatif digial harus menjawab tantangan dari pelanggan melalui inovasi,yang dilakukan dengan tiga pendekatan yaitu eksplorasi, ekploitasi, dan learning. Eksplorasi adalah kemungkian produk baru dikembangkan dan dipromosikan sehingga produk tersebut sukses dipasarkan / eksploitasi (sukses secara ekonomi). Eksplorasi dan eksploitasi dilakukan melalui proses learning.

Dari hasil analisis terhadap hasil pengumpulan data di lapangan dan kegiatan Focus Group Discussion (FGD) yang dilakukan tiga kali dengan melibatkan tim peneliti, industri kreatif digital, komunitas industri kreatif digital, dan expert di bidang industri kreatif maka direkomendasikan beberapa strategi inovasi yang bisa dilakukan industri kreatif digital di Jawa barat dengan dukungan teknologi sebagai berikut :

1. Tetap mengutamakan kualitas

Kualitas tetap menjadi tujuan dari suatu aktifitas bisnis. Saat ini konsumen memiliki banyak pilihan untuk setiap jenis produk yang ditawarkan sehingga kualitas tetap menjadi prioritas yang sangat penting untuk tetap dijaga. Inovasi produk dalam bentuk pengembangan atribut produk yang dapat meningkatkan kualitas produk dan nilai tambah/value added produk harus dioptimalkan. Penerapan teknologi baru dalam proses produksi merupakan salah satu cara untuk meningkatkan kualitas produk. Layanan purna jual dan pemeliharaan produk juga dapat ditawarkan sebagai upaya untuk meningkatkan kualitas produk

2. Meningkatkan kompetensi, daya kreatifitas dan daya inovasi karyawan sebagai ujung tombak proses inovasi didalam perusahaan melalui berbagai pelatihan-pelatihan profesional. Perusahaan harus menjadikan kebijakan pelatihan tersebut sebagai cara untuk berinvestasi untuk meningkatkan kinerja perusahaan karean sumberdaya yang kompeten, kreatif, dan inovatif merupakan asset yang sangat berharga.

3. Mengembangkan sistem penghargaan/reward system kepada karyawan untuk meningkatkan motivasi selalu berinovasi.

4. Mengembangkan website

Website memiliki banyak fungsi, yaitu memperkenalkan brand dan identitas perusahaan juga sebagai media promosi. Website yang dibuat harus menggambarkan identitas produk, informatif, dan user friendly/mudah digunakan sehingga strategi pemilihan isi website dan tampilan website yang tepat harus diperhatikan.

5. Berkolaborasi dengan social influencer

Social influencer adalah individu yang bisa berasal dari kalangan dan profesi apapun yang 
memiliki kemampuan untuk memberikan pengaruh kepada orang laian untuk mengikuti apa yang dikatakan, difikirkan, dan dilakukan. Menggunakan social influencer untuk mempromosikan produk perusahaan diharapkan dapat mempengaruhi dan menyebabkan orang lain menggunakan produk perusahaan.

6. Manfaatkan media sosial sebagai sarana/tools promosi

Media sosial digunakan sebagai tools promosi untuk meningkatkan efektifitas promosi karena promosi langsung tepat kepada konsumen. Media sosial dapat menjadi sarana untuk mengetahui perkembangan kebutuhan dan keinginan konsumen. Media sosial juga dapat digunakan untuk memantau strategi yang dilakukan oleh indutri kreatif. Amati perkembangan terbaru dari media sosial

7. Gunakan pemasaran secara offline dan online

Walaupun teknologi informasi, komunikasi dan logistik berkembang dengan cepat tetapi kombinasi saluran pemasaran secara offline dan online tetap harus dilakukan untuk memperluas pangsa pasar dan mempertahankan pangsa pasar yang sudah ada.

\section{Peningkatan Daya Saing Industi Kreatif Digital di Era 4.0: Pendekatan Inkubator Bisnis bagi Start Up Digital}

Salah satu strategi pemerintah untuk meningkatkan daya saing industri kreatif digital melalui pendekatan sistem adalah melalui inkubator bisnis. Strategi inkubator bisnis merupakan strategi yang paling tepat untuk industri yang berada pada fase start up. Hasil penelitian mengidentifikasikan bahwa mayoritas industri kreatif digital di Provinsi Jawa Barat yaitu $88 \%$ berada pada fase start up karena memiliki lama usaha 0-5 tahun sehingga inkubator bisnis menjadi strategi yang tepat bagi pengembangan industri kreatif digital di Provinsi Jawa Barat. Pemerintah melalui Kemenparekraf telah mengembangkan inkubator bisnis di beberapa wilayah seperti Bandung, Bali, Makasar, Jakarta, dan Yogyakarta. Bandung adalah kota yang menjadi pusat industri kreatif digital di Jawa Barat. Beberapa faktor menjadi potensi untuk tumbuh dan berkembangkanya industri kreatif digital di Bandung, diantaranya adalah: keterbukaan masyarakat terhadap ide-ide baru, kedekatan dengan institusi-institusi pendidikan yang dapat menjadi sumber SDM inovatif, dukungan pemerintah daerah, serta kekayaan budaya lokal yang dapat menjadi ciri khas bagi suatu produk digital.

Di kota Bandung pemerintah membangun techno park yang memiliki beberapa program antara lain pelatihan bagi calon pemimpin perusahaan yang menggunakan basis industri 4.0..Pemerintah juga mendorong keterlibatan pihak swasta untuk membangun inkubasi startup era digital. Keterlibatan pihak swasta dalam pengembangan inkubator bisnis pada industri kreatif digital di Jawa barat salah satunnya dapat dilihat dari pembentukan Bandung Digital Valley oleh PT. Telkom Indonesia, Tbk. Salah satu program yang dikembangkan adalah Program Indigo.Program Indigo melakukan pembinaaan terhadap start up digital melalui inkubator bisnis. 
Secara umum, inkubator bisnis merupakan strategi dimana sekelompok entitas yang memiliki karakteristik dan tujuan disatukan untuk bersinergi dan mencapai tujuan bersama. Inkubator bisnis juga mendorong terjadinya transfer ilmu dan pengalaman yang memperkuat anggota di dalamnya. Hal yang sama juga menjadi tujuan dari pengembangan inkubator industri kreatif bisnis digital. Dalam menjalankan bisnisnya, startup akan menemui banyak risiko. Hal ini disebabkan beberapa faktor, salah satunya adalah kurangnya pendanaan dan pengalaman. Inkubator bisnis dapat dianggap sebagai sarana untuk mematangkan startup. Inkubator bisnis dapat menjadi fasilitator yang akan memberikan pendampingan dan dukungan pada startup dalam merancang bisnis yang akan dijalankan. Dukungan tersebut dapat berupa dukungan fisik yaitu penyediaan co-working space, perangkat teknologi, akses internet, hingga dukungan non-fisik seperti workshop, coaching, mentoring, dan bantuan finansial.

Merujuk kepada sistem inkubasi yang dikembangkan oleh incubie LPPM Institut Pertanian Bogor (IPB), maka terdapat tiga tahapan dalam inkubator bisnis bagi startup untuk terus bertumbuh sampai bisa dikatakatan dewasa atau "mature" memasuki dunia luar, yaitu pra inkubasi (preincubation), inkubasi (incubation), dan pasca inkubasi (post-incubation). Tiga tahapan tersebut dijelaskan pada Gambar 1.

Pra inkubasi adalah tahap dimana pendamping membantu sekelompok start up yang memiliki ide dan melakukan seleksi. Tahap inkubasi terdiri dari tahap awal, pengembangan, dan tahap lanjutan. Pada tahap inkubasi, ide diaktualisasikan dalam bentuk rencana bisnis, pelatihan, dan uji coba produksi serta aspek legalitas. Inkubator dapat membantu dalam perencanaan, membantu tim, menyediakan sumberdaya, dan investasi. Pada tahap pengembangan, start up melakukan produksi awal, kemudian uji coba pasar untuk melihat respon pasar terhadap produk yang dihasilkan dan melakukan sertifikasi dan standarisasi. Pada tahap lanjutan, start up mulai melakukan produksi secara komersial, kemudian diperkuat lagi dengan perluasan pasar dan pengembangan network/jejaring. Pada pasca inkubasi, inkubator sudah dapat melepas tenant dan dihasilkan UMKM yang inovatif, mandiri, dan berdaya saing.

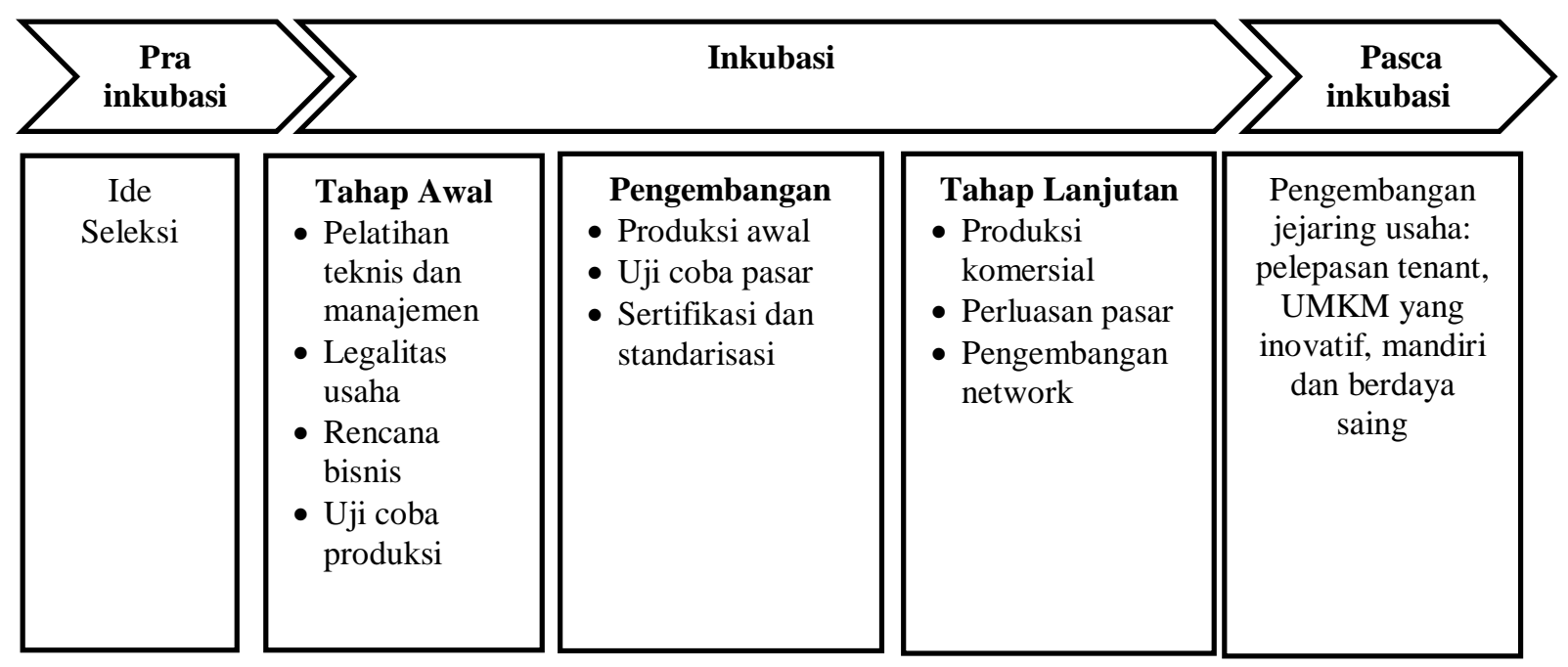

Gambar 1.Tahapan-Tahapan Inkubator Bisnis

Sumber: Adaptasi dari Model Inkubasi, http://incubie.ipb.ac.id/model-inkubasi, 2019 


\section{KESIMPULAN DAN SARAN}

Hasil penelitian terhadap industry kreatif digital di Jawa Barat yang dilakukan selama tahun 2017-2019 memberikan gambaran bahwa aspek inovasi menjadi salah satu faktor penghambat/bottleneck untuk tumbuh dan berkembangnya industri kreatif digital di Jawa Barat. Pelaku usaha cukup terbuka dengan ide-ide baru untuk mengembangkan proses produksi dan kualitas produksi serta telah menjadikan aspek inovasi sebagai bagian dari strategi bisnis. Namun sebagian besar responden belum mengetahui jenis dan bagaimana strategi inovasi itu harus dilaksanakan. Keterlibatan seluruh sumberdaya manusia di dalam perusahaan dalam proses inovasi juga masih harus ditingkatkan. Bebrapa strategi inovasi yang dapat dilakukan adalah inovasi produk, inovasi proses, dan inovasi pemasaran. Strategi inovasi dengan pendekatan sistem dapat dilakukan melalui pendekatan inkubator bisnis. Hasil penelitian diharapkan dapat memberikan implikasi dalam bentuk strategi bisnis perusahaan dan kebijakan yang dapat dikeluarkan pemerintah daerah untuk menciptakan iklim yang kondusif bagi tumbuh dan berkembangnya industri kreatif digital di Jawa Barat.

Penelitian ini memiliki keterbatasan karena hanya dilakukan di Provinsi Jawa Barat saja. Penelitian lanjutan perlu dilakukan pada cakupan penelitian yang lebih luas, misalnya Provinsi DKI Jakarta dan Yogyakarta sebagai pusat industri kreatif digital selain Jawa Barat. Penelitian lanjutan diperlukan agar diperoleh gambaran secara komprehensif bagaimana industri kreatif digital melakukan inovasi, identifikasi potensi dan kendala pengembangan serta strategi yang perlu dilakukan untuk meningkatkan keunggulan bersaing melalui strategi inovasi.

\section{REFERENSI}

Badan Pusat Statistik dan Badan Ekonomi Kreatif. 2017. Data Statistik dan Hasil Survei Ekonomi Kreatif.

Chodorek, Monika and Copernicus, Nicolaus. 2012. The Place and Role of Talent Management in the Positive Organizational Potential: An Empirical Study of Companies Operating in Poland. CF, 10, p.25-32

Heizer, Jay and Render, Barry. 2017. Operations Management. $11^{\text {th }}$ Edition. New Jersey: Pearson Education International

Hernández, Manuel Lorenzo. 2010. Basic Concepts of Innovation and Innovation Management, Student Material. Head of Technology \& Innovation. Ericsson España S.A.

Hotho, Sabine and Champion, Katherine. 2010. We Are Always After That Balance" - Managing Innovation in the New Digital Media Industries. Journal of Technology Management \& Innovation 5.

Keeley, L.,Walters, H., Pikkel, R., Quinn, B. 2013. Ten Types of Innovation: The Discipline of Building Breakthroughs. New York: John Wiley and Sons, Inc.

Kementrian Pariwisata dan Ekonomi Kreatif. 2015. Cetak Biru Pengembangan Industri Kreatif tahun 2015-2025.

LPPM IPB. 2019. Model Inkubasi. Diambil dari: http://incubie.ipb.ac.id/model-inkubasi. (15 September 2019)

Lu, Feng and Mu, Ling. 2011. Learning by Innovating: Lessons from China's Digital Video Player Industry. Journal of Science and Technology Policy in China, 2, p.27-57. 
Putra, C.N. 2018. Bekraf Outlook Ekonomi Kreatif (Opus) 2019. Diambil dari: https://bekraf.go.id/berita/page/10/bekrf-outlook-ekonomi-kreatif-opus-2019 (12 September 2019.

Urabe, Kuniyohi. 1988. Innovation and Management. Berlin: De Gruyter Publisher.

Van de Ven, Andrew H. 2016. The Innovation Journey: You Can't Control It, But You Can Learn To Maneuver It. Innovation : Organization \& Management Journal. 19, p.1-7.

$\mathrm{Xu}$, Qingrui, et al. 2006. Total Innovation Management: A Novel Paradigm of Innovation Management in the 21st Century. Journal Technology Transfer. 32, p.9-25. 